\title{
Gene Expression Related to Physiological Quality of Soybean Seeds
}

\author{
Kiliany A. A. Moreno ${ }^{1}$, Raquel M. O. Pires ${ }^{2}$, Maria L. R. Castro ${ }^{2}$, Renato C. C. Vasconcellos ${ }^{2}$, \\ Heloisa O. Santos ${ }^{2} \&$ Édila V. R. V. Pinho ${ }^{2}$ \\ ${ }^{1}$ Biology Departament, Del Cauca University, Popayán, Colombia \\ ${ }^{2}$ Department of Agriculture, Lavras Federal University, Lavras, Brazil \\ Correspondence: Raquel M. O. Pires, Department of Agriculture, Lavras Federal University, Lavras, MG, \\ 37200-000, Brazil. Tel: 55-31-97361-1864. E-mail: raquel.mopires@gmail.com
}

Received: October 31, 2018

doi:10.5539/jas.v11n3p370

\author{
Accepted: December 9, 2018 \\ Online Published: February 15, 2019 \\ URL: https://doi.org/10.5539/jas.v11n3p370
}

\begin{abstract}
Production of soybeans with high physiological quality is important to ensure the productivity of improved plant populations. The objective of this work was to select soybean genotypes for high physiological quality of seeds, through germination and vigor tests, and to study gene expression by transcripts and proteins. In a first trial, seeds of 12 soybean cultivars were evaluated and selected six cultivars with contrasting physiological quality levels. At the protein level, the isoenzyme systems alcohol dehydrogenase (ADH), malate dehydrogenase $(\mathrm{MDH})$, phosphoglucose isomerase (PGI), sorbitol dehydrogenase (SDH), superoxide dismutase (SOD), catalase (CAT), isocitrate lyase (ICL), esterase (EST), glutamate oxaloacetate transferase (GOT), and heat-resistant proteins were evaluated. For the transcript levels, the real-time PCR technique (qRT-PCR) was used, and the genes coding for the SOD, CAT, MDH, PGI, ICL and PRX enzymes were studied. The germination and vigor tests classified the seeds of cultivars CD201, CA115 and MS8400 as high quality, while the cultivars Syn1263, Syn1279 and CD202 were classified as of low quality. The enzymes involved in the process such as dehydrogenase and phosphoglucose isomerase, are promising markers for assessing the physiological quality of soybean seeds. Higher expression of peroxiredoxin enzyme is related to the low physiological quality of soybean seeds.
\end{abstract}

Keywords: Glycine max, isoenzymes, transcriptomics, proteomics, germination, vigor

\section{Introduction}

The development of soybean cultivars with good agronomic characteristics in the sowing and grain industry has increased significantly in recent years in Brazil. Through research, genetic diversity for physiological quality has been observed among soybean cultivars. Improving studies in this line of research is important due to climatic conditions in Brazil during the seed production process. Mainly after the physiological maturity of the seeds, the high temperature and the relative humidity that can accelerate the deterioration process, which leads to the reduction of the physiological quality of seeds.

In the process of seed deterioration a few enzymes are involved that act in respiratory processes, such as alcohol dehydrogenase $(\mathrm{ADH})$, malate dehydrogenase (MDH) and phosphoglucose isomerase (PGI), in addition to those related to the removal of free radicals such as superoxide dismutase (SOD) and catalase (CAT) and also those related to the degradation of reserve materials such as isocitrate lyase (ICL), among others.

In breeding programs, it has increasingly sought to improve technologies for the selection of soybean cultivars with high physiological quality of the seeds. In general, germination and vigor tests have been used in this selection process. However, knowledge at the molecular level, mainly through transcriptomic and proteomic techniques, allows advances in obtaining high-quality seed cultivars. The qualitative and quantitative determination of transcript levels related to the physiological quality of seeds allows differentiated genes to be identified and their metabolic function investigated (Kuhn et al., 2001). Studying genes related to the physiological quality of seeds has been a challenge, mainly due to its genetic control.

The objective of this study was to identify soybean genotypes for physiological quality characteristics by germination and vigor tests and to study the expression of genes, transcripts and proteins, related to the physiological quality of seeds. 


\section{Material and Methods}

The experiments were conducted in the Central Seed Laboratory and the experimental area of the Department of Agriculture of the Lavras Federal University (UFLA), in Lavras, MG, Brazil.

Initially, for the selection of contrasting genotypes for physiological quality, seeds of 12 conventional soybean cultivars were used: CD201, SYN1263, SYN1279, BMX Potência, UFLA1, CA115, MSoy-8400, CD215, CD202, Conquista, Savana and BRS 820, from the germplasm bank of the Lavras Federal University. For seed multiplication, a randomized complete block design with three replications was used. The experimental units consisted of 4 lines of $5 \mathrm{~m}$ each, considering only the 2 central lines as useful area. The thinning was carried out maintaining a population of 16 plants per linear meter.

The experiment was sowed using the conventional system with previous desiccation of the weeds, before sowing the soybean, which was performed between 15th and 25th of November, 2015. The fertilization and the management were carried out according to the recommendations for the culture.

The seeds were harvested at the R8 stage ( $95 \%$ maturity of the seeds, with a water content of $18 \%$ ). Subsequently, they were dried naturally to $12 \%$ water content. In the processing, circular sieve was used, between $5.55 \mathrm{~mm}$ and $6.35 \mathrm{~mm}$, to standardize the seed size. They were then weighed and stored in paper bags under controlled cold chamber conditions at $10{ }^{\circ} \mathrm{C}$ until the next stage of the experiment.

Physiological tests were carried out to identify six contrasting cultivars for physiological quality: CD201, CA115, MS8400, CD202, Syn 1263 and Syn1279. These were again sowed in the field for seed maintenance and multiplication. In addition, they were evaluated for physiological quality, and proteins and transcripts expression.

For the germination and accelerated aging tests, the seeds were treated with Vitavax Thiram 200SC fungicide at $250 \mathrm{ml} / \mathrm{kg}$ of seeds dosage. 200 seeds per cultivar were used in both tests.

In the germination test, the seeds were sowed on Germitest paper moistened with distilled water in the proportion of 2.5 times the weight of the paper, aiming an adequate moistening and uniformity of the test. The seeds remained in the germinator at $25{ }^{\circ} \mathrm{C}$. Evaluations were performed at five days (first count) and eight days (final count), computing the percentage of normal seedlings, according to the criteria established in the Brazilian Rules for Seed Analysis (Brasil, 2009)

For the accelerated aging test, gerbox minicameras were used, in which $42 \mathrm{~g}$ of seeds were distributed on a screen suspended inside the box containing $40 \mathrm{~mL}$ of water and submitted to $42{ }^{\circ} \mathrm{C}$ for 72 and 82 hours. Afterward the germination test was carried out. A single reading was performed on the fifth day after sowing, and the percentage of normal seedlings was computed (Brasil, 2009).

Controlled deterioration was evaluated using samples of 42 grams of seeds, for each cultivar. These were artificially moistened until reaching a water content of $15 \%$, according to Rossetto and Marcos Filho (1995), and placed in hermetically sealed plastic coated aluminum sachets. These were kept in a water bath at $40{ }^{\circ} \mathrm{C}$ for 48 hours. Then, a germination test was performed, and evaluated on the fifth day after sowing, according to the previous item (ISTA, 1995; Rosseto \& Marcos Filho, 1995).

For the electrical conductivity test, four replicates of 50 seeds were used for each cultivar, apparently intact and then weighted. They were then placed in plastic cups with a capacity of $200 \mathrm{ml}$ containing $75 \mathrm{ml}$ of deionized water for 24 hours at $25^{\circ} \mathrm{C}$. The conductivity of the seed soak solution of each cultivar was measured by means on a CD 21A (DIGIMED) conductivity equipment, and the results were expressed in $\mu \mathrm{S} / \mathrm{cm} / \mathrm{g}$ of seeds (Vieira \& Carvalho, 1994).

Statistical analysis was performed using the Sisvar software (Ferreira, 2011) and the data were interpreted through the analysis of variance. The Scott-Knott test was used at 5\% probability, for comparison of means.

After the harvest, part of the seeds was immediately conditioned in liquid nitrogen and stored at $-80{ }^{\circ} \mathrm{C}$ for further analysis of gene expression related to the physiological quality of seeds. The real-time PCR (qPCR) technique was used for the transcripts analysis and the technique of electrophoresis for protein analysis.

In the gene expression analysis, an amount of 50 seeds per treatment/cultivar, was removed and conditioned in the deep freezer for later analysis of the activities of the main enzymes of the seed metabolism.

The crude enzymatic extracts were obtained by the maceration of the seeds in the presence of PVP (polyvinylpyrrolidone) and liquid nitrogen, and later stored at $-86^{\circ} \mathrm{C}$. 
The electrophoretic run was performed in a discontinuous system of $7.5 \%$ polyacrylamide gels (separator gel) and $4.5 \%$ (concentrator gel). The gel/electrode system used was Tris-glycine $\mathrm{pH} 8.9 .50 \mu \mathrm{l}$ of the sample supernatant was applied to the gel well and the run performed at $150 \mathrm{~V}$ for 5 hours.

At the end of the run, the gels were developed for the enzymes alcohol dehydrogenase (ADH-EC 1.1.1.1), malate dehydrogenase (MDH-EC 1.1.1.37), Esterase (EST-EC 3.1.1.1), Catalase (CAT-EC 1.11.1.6), Superoxide dismutase (SOD-EC 1.15.1.1), Isocitrate lyase (ICL-EC 4.1.3.1), glutamate dehydrogenase (GTDH-EC 1.4.1.2), phosphoglucose isomerase (PGI), sorbitol dehydrogenase (SDH) and LEA proteins. The gels for each enzyme were evaluated on a transilluminator, considering the intensity variation of the bands, as well as their absence and presence.

The extraction of RNA was performed by maceration of five seeds of each cultivar, in liquid nitrogen. Afterward, all the materials used were previously submitted $\mathrm{H}_{2} \mathrm{O}$ treated with $0.1 \%$ DEPC (diethylpyrocarbonate) to inhibit the action of the RNAs enzymes. The total RNA was extracted in two biological replicates for each sample using PureLink Plant RNA reagent (Invitrogen) according to the manufacturer's recommendations and, for $0.1 \mathrm{~g}$ of the seeds, $500 \mu \mathrm{L}$ of PureLink Plant RNA, vortexed for 20 seconds and maintained in the horizontal position for 5 min, for better homogenization of the material. The material was then centrifuged at $14,000 \mathrm{rpm}, 4^{\circ} \mathrm{C}$ for $15 \mathrm{~min}$. After centrifugation, the supernatant was transferred to a new microtube, adding $300 \mu \mathrm{L}$ of chloroform, $100 \mu \mathrm{L}$ of potassium chloride $(5 \mathrm{M})$, followed by stirring.

Centrifugation was performed again at $14,000 \mathrm{rpm}, 4{ }^{\circ} \mathrm{C}$ for $10 \mathrm{~min}$. The supernatant was transferred to a new microtube with the same volume of isopropyl alcohol and the microtube held for $10 \mathrm{~min}$. Subsequently, the material was centrifuged at $14,000 \mathrm{rpm}$ at $4{ }^{\circ} \mathrm{C}$ for $10 \mathrm{~min}$. Thereafter, the supernatant was discarded and $1 \mathrm{ml}$ of $70 \%$ ethanol was added and centrifuged at $14,000 \mathrm{rpm}$ at room temperature for $1 \mathrm{~min}$. The supernatant was removed and the pellet dried for $10 \mathrm{~min}$, which was resuspended in $20 \mu \mathrm{l}$ of water with $0.1 \%$ DEPC and stored at $-80{ }^{\circ} \mathrm{C}$. The quantification of total RNA extracted was done in a spectrophotometer, measuring the absorbance at 260 and $280 \mathrm{~nm}$, observing the wavelength ratio 260/280, whose values were in the range 1.8 to 2.0 , which indicates high-quality extraction. The integrity of the RNA was also analyzed by agarose gel electrophoresis $(1.5 \%)$, containing $1 \times \mathrm{TBE}$ buffer and stained with ethidium bromide solution. The race took place at $90 \mathrm{~V}$ for $30 \mathrm{~min}$.

The extracted RNA samples were treated with DNase (Ambion) according to the manufacturer's instructions. To obtain the cDNA, the Hight-Capacity cDNA Reverse Transcription kit (Applied Biosystems) was used.

For the primers design, the NCBI genebank was used. Sequences of the different genes encoding the enzymes evaluated were selected. Subsequently, the primers were designed using the Primer Express 3 program (Applied Biosystems) (Table 1). GAPDH (glyceraldehyde-3-phosphate dehydrogenase) and CYP2 (peptidyl-prolylcistransisomerase2) genes were chosen as reference for the qRT-PCR analysis.

Table 1. Primers used in the qRT-PCR analysis to selected cultivars of high and low physiological quality

\begin{tabular}{ll}
\hline Gene & Primer Sequence \\
\hline GAPDH F & 5' TCCAAGGGGACCTAACGGAGA 3' \\
GAPDH R & 5' TGGGTCAAGAGCTGGATGGTG 3' \\
CYP2 F & 5' CGGGACCAGTGTGCTTCTTCA 3' \\
CYP2 R & 5' CCCCTCCACTACAAAGGCTCG 3' \\
SOD F & 5' GTTGAAAAGCCA GGGGACA 3' \\
SOD R & 5' TCTTACCCCTTGA GCGTGG 3' \\
PRXF & 5' TCCTGACTATTATTTCCGCATCAC 3', \\
PRX R & 5' TTATCACACATGCGCTTGAATTT 3' \\
CAT F & 5' TGTTGCTGCAGTTGCGTACA 3' \\
CAT R & 5' CGGAAAACCAAGTCTCATCAACTA 3' \\
PGI F & 5' AACAACGGCACTGACAGTTACG 3' \\
PGI R & 5' GAGCACCACCCTGTTTGGT 3' \\
MDH F & 5' GGCACCCTGTTTGGTGGGACA 3' \\
MDH R & 5' GTTGAAAAGCCA GGGGACA 3' \\
ICL F & 5' TGGGTCAAGAGCTGGATGGTG 3' \\
ICL R & 5' CGGGACCAGTGTGCTTCTTCA 3', \\
\hline
\end{tabular}

Note. (F) forward primer sequence. (R) reverse primer sequence. 
Reaction conditions were $50^{\circ} \mathrm{C}$ for $2 \mathrm{~min}, 95^{\circ} \mathrm{C}$ for $10 \mathrm{~min}, 45$ cycles of $95{ }^{\circ} \mathrm{C}$ for $2 \mathrm{~min}, 62^{\circ} \mathrm{C}$ for $30 \mathrm{sec}$ and $72{ }^{\circ} \mathrm{C}$ for $30 \mathrm{sec}$. The amplification reactions were conducted in a final reaction volume of $20 \mu \mathrm{L}$ containing: 10 $\mu \mathrm{L}$ of SYBR Green PCR Master Mix (Applied Biosystems), $2 \mu \mathrm{L}$ cDNA (250 ng), $0.4 \mu \mathrm{L}$ of each of the forward and reverse primers and $7.2 \mu \mathrm{L}$ of autoclaved ultrapure water.

After amplification by real-time PCR, each amplification product was analyzed by a dissociation curve, certifying that for each gene and treatment, the amplified product had no non-specific bands and/or formation of primer dimers. Data analysis was performed using the 7500 Software SDS (Version 2.0.1) (Applied Biosystems).

\section{Results and Discussion}

There was a significant difference in the physiological quality of soybean seeds between cultivars by the majority of germination and vigor tests $(\mathrm{P}<0.05)$ in the first experiment in which seeds of 12 cultivars were evaluated (Table 2).

Table 2. Means obtained from the physiological tests: accelerated aging (E.A), at 72 hours; accelerated aging at 82 hours; first germination count (PC\%), final count of germination (GER\%); controlled deterioration (D.C) at 5 and 7 days of 12 cultivars of soybean seeds of produced in the first experiment

\begin{tabular}{llllll}
\hline Cultivars & EA (72 hours) & EA (82 hours) & PC\% & GER (\%) & DC (5 days) \\
\hline Syn1263 & $92.0 \mathrm{~b}$ & $13.0 \mathrm{e}$ & $95.0 \mathrm{a}$ & $97.0 \mathrm{~b}$ & $98.0 \mathrm{a}$ \\
CD 202 & $93.0 \mathrm{~b}$ & $13.0 \mathrm{e}$ & $98.0 \mathrm{a}$ & $100 \mathrm{a}$ & $95.0 \mathrm{a}$ \\
Syn 1279 & $86.0 \mathrm{~b}$ & $26.0 \mathrm{~d}$ & $98.0 \mathrm{a}$ & $99.0 \mathrm{a}$ & $98.0 \mathrm{a}$ \\
CD 215 & $87.0 \mathrm{~b}$ & $27.0 \mathrm{~d}$ & $99.0 \mathrm{a}$ & $99.0 \mathrm{a}$ & $97.0 \mathrm{a}$ \\
BRS 820 & $96.0 \mathrm{a}$ & $30.0 \mathrm{~d}$ & $98.0 \mathrm{a}$ & $98.0 \mathrm{a}$ & $98.0 \mathrm{a}$ \\
Conquista & $93.0 \mathrm{~b}$ & $31.0 \mathrm{~d}$ & $91.0 \mathrm{~b}$ & $96.0 \mathrm{~b}$ & $94.0 \mathrm{a}$ \\
Savana & $91.0 \mathrm{~b}$ & $32.0 \mathrm{~d}$ & $88.0 \mathrm{~b}$ & $95.0 \mathrm{~b}$ & $90.0 \mathrm{a}$ \\
UFLA 1 & $93.0 \mathrm{~b}$ & $34.0 \mathrm{~d}$ & $96.0 \mathrm{a}$ & $97.0 \mathrm{~b}$ & $98.0 \mathrm{a}$ \\
BMX pot. & $91.0 \mathrm{~b}$ & $41.0 \mathrm{c}$ & $96.0 \mathrm{a}$ & $97.0 \mathrm{~b}$ & $96.0 \mathrm{a}$ \\
CA 115 & $97.0 \mathrm{a}$ & $41.0 \mathrm{c}$ & $98.0 \mathrm{a}$ & $99.0 \mathrm{a}$ & $96.0 \mathrm{a}$ \\
CD201 & $100 \mathrm{a}$ & $63.0 \mathrm{~b}$ & $98.0 \mathrm{a}$ & $99.0 \mathrm{a}$ & $98.0 \mathrm{a}$ \\
MS 8400 & $97.0 \mathrm{a}$ & $73.0 \mathrm{a}$ & $98.0 \mathrm{a}$ & $99.0 \mathrm{a}$ & $95.0 \mathrm{a}$ \\
\hdashline CV\% & 3.88 & 15.39 & 2.77 & 1.73 & 3.10 \\
\hline
\end{tabular}

Note. Means followed by the same lowercase letter in the column do not differ by Scott-Knott's test, at $5 \%$ significance.

The accelerated aging test for 82 hours allowed greater separation between cultivars. Under these conditions, higher values of vigor were observed in seeds of cultivar MS8400, followed by cultivar CD 201 and lower values were observed for cultivars Syn 1263 and CD202. For the other cultivars, intermediate values were observed. When the seeds were aged for 72 hours and evaluated on the fifth day, there was less distinction among the cultivars regarding vigor.

At the first germination count, lower values were observed for the cultivars Conquista and Savana. In the final count, in addition to the cultivars Conquista and Savana classified with lower seed vigor, also the seeds of cultivars SYN 1263, UFLA 1 and BMX Potência presented low physiological quality.

In the controlled deterioration test, there was no statistical difference between the vigor values of the seeds of the twelve cultivars evaluated.

With the result analysis obtained in this first trial, and also based on the previously results in the researches of Baldoni (2013) and Menezes (2008), it was decided to select cultivars and to divide them into two groups: those that presented seeds with high physiological quality (CD201, CA115 and MS8400) and with low physiological quality (YN 1263, SYN 1279 and CD 202).

Table 3 shows the results of germination and vigor tests of the second trial, with the results of the six soybean cultivars, selected as the most contrasting.

In both the first count and the final germination count, the lowest value was verified in seeds of cultivar CD202. For the other cultivars, there was no statistically significant difference between the values. When seeds were 
submitted to artificial aging for 72 hours and 82 hours, the lowest values of vigor were observed in seeds of cultivar SYN 1263. In these evaluations, low vigor was also observed in seeds of cultivar CD 202.

When analyzing the results of electrical conductivity it was verified that it was not possible to associate the physiological quality with the conductivity values. The lowest values of electrical conductivity were observed in the MS 8400 and CD 202 cultivars, the first being classified as high quality and the second with low physiological quality. The highest values were observed in seeds of cultivars CD 201 and CD 202, also differing in the physiological quality traits.

The CD 201 is a conventional cultivar and has been used in different studies of productivity and physiological quality. Menezes et al. (2009) made a selection of genotypes for the physiological quality trait of seeds and observed that the cultivars CD201 and MS-8400 were more vigorous, as verified in the present work. Similar results were also observed by Baldoni (2013).

The CA 115 cultivar, classified as high quality, has the RR 2 Bt technology but is not yet commercially available. On the other hand, cultivars considered of low quality, such as Syn 1263 and Syn 1379, present high productivity, but with low vigor seeds, which makes their recommendation in the market unfeasible (Ferreira, 2015). In works by Menezes et al. (2009) and Minuzzi et al. (2010) cultivar CD 202 was selected as low quality.

Researches related to the selection of cultivars for their physiological quality traits show variations in germination and vigor values in seeds of the same cultivars, produced in different locations and harvests. This situation demonstrates the complexity of the genetic control for this trait in soybean seeds, suggesting that this trait is controlled by several genes and influenced by the environment.

In the gene expression analysis, the enzyme alcohol dehydrogenase (ADH), related to the anaerobic respiration, promoting the reduction of acetaldehyde to ethanol, showed higher activity in cultivars CD201, MS8400 and CA115, considered of higher physiological quality (Figure 1A).

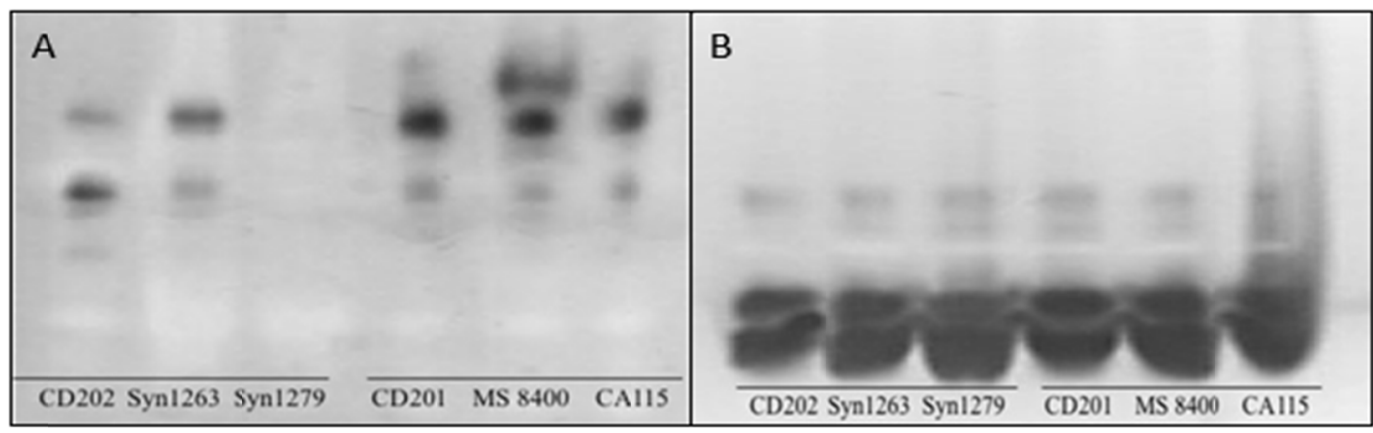

Figure 1. Isoenzymatic patterns in soybean seeds of cultivars CD202, SYN 1363, SYN1279, CD 201, MS8400, CA 115, revealed for the enzyme alcohol dehydrogenase (ADH) (Figure 1A) and malate dehydrogenase (MDH) (Figure 1B)

Baldoni (2013) observed similar results in seeds of these cultivars, both in seeds harvested at the R8 stage, and those harvested 15 days after the R8 stage, possibly because they are more vulnerable to deterioration and consequently with higher production of acetaldehyde, considered more toxic to the seeds, when compared to the ethanol (Zhang et al., 2008). Similar patterns for ADH activity were found by Vidigal (2009).

Carvalho et al. (2014) found higher ADH expression in soybean cultivars that presented better physiological quality. The seeds can be less susceptible to the deleterious action of acetaldehyde, with a higher ADH activity (Veiga et al., 2010).

Regarding the expression of the MDH enzyme (Figure 1B), similar patterns were observed for all cultivars evaluated. The enzyme malate dehydrogenase (MDH) has been associated with oxaloacetate biosynthesis (OAA) by the interconversion of malate to oxaloacetate during the cycle of tricarboxylic acids (Krebs cycle) in plants (Gasparmalone et al., 2007). Thus, this enzyme assumes an important function in a wide variety of biosynthetic reactions, which justifies its greater activity in the first stages of the germination process (Gasparmalone et al., 2007). In addition, as a result of the deterioration process, there is a compromise of the respiratory activity of the seeds. Therefore, seeds of lower physiological quality present less activity of enzymes related to respiration. 
The zymogram for the enzyme phosphoglucose isomerase (PGI) is shown in Figure 2A. The expression of this enzyme was higher in seeds of cultivars CD 201 and CA 115 classified as high quality. This high expression is associated with the effectiveness of the enzyme in the glycolysis process of phosphorylation of sugars, important for energy production during respiration. It is important to emphasize that in seeds of cultivar MS 8400, PGI expression was similar to that observed in low-quality seeds.

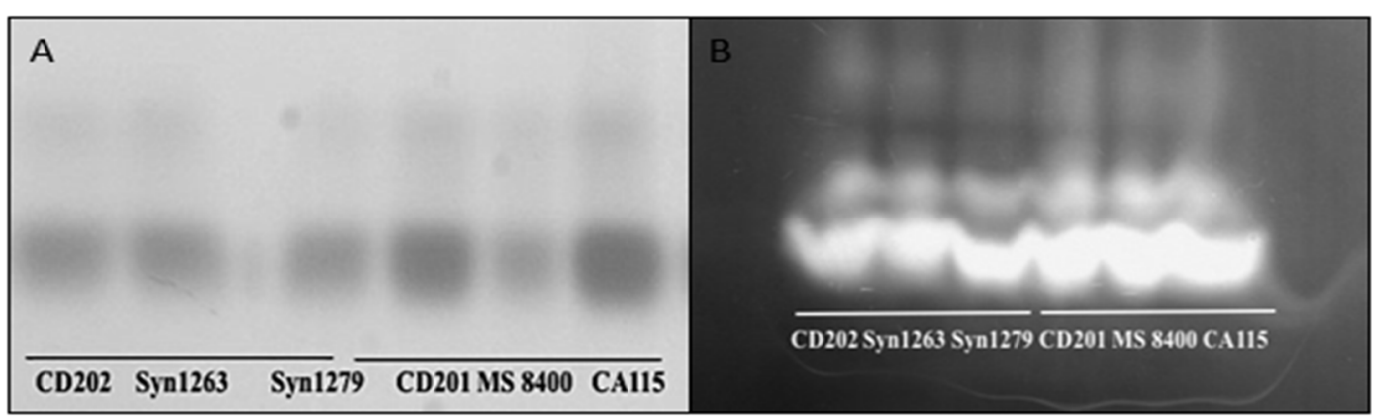

Figure 2. Isoezymatic patterns in soybean seeds of cultivars CD202, SYN 1363, SYN1279, CD 201, MS8400, CA 115 , revealed for the enzyme phosphoglucose isomerase (PGI) (Figure 2A) and sorbitol dehydrogenase (SDH) (Figure 2B)

For the sorbitol dehydrogenase (SDH) enzyme (Figure 2B), the highest activity was verified in seeds of the high-quality cultivars, CD201, Ms8400 and CA115. SDH is an important enzyme in aerobic respiration, acting on the metabolic route of glycolysis and acting on the conversion of glucose to fructose. Basavarajappa, Shetty, and Prakash (1991) found a decrease in the activity of this enzyme in maize seeds, considered of low quality, associating its loss of activity with low levels of ATP production.

As for the results obtained for the SOD enzyme, higher activity was observed in seeds classified as low quality, CD 202, Syn1263 and Syn1279, (Figure 3A). SOD is considered a free radical scavenger enzyme and is one of the first to act in defense against reactive oxygen species (ROS). The low physiological quality may be associated with the higher SOD activity, and it is possible that this behavior is related to the elimination of ROS, present in seeds of these cultivars. The hydrogen peroxide, formed as a product of SOD, although less reactive than acetaldehyde, in high concentrations, becomes toxic, as it can react forming hydroxyl radicals, which cause lipid peroxidation (Resende et al., 2003).
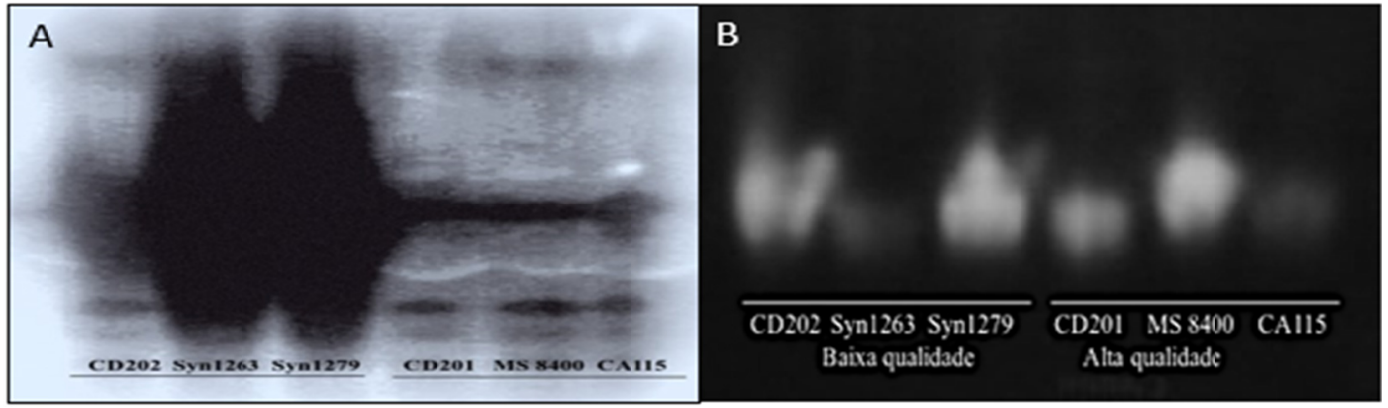

Figure 3. Isoezymatic patterns in soybean seeds of cultivars CD202, SYN1363, SYN1279, CD 201, MS8400, CA 115, revealed for the enzyme superoxide dismutase (SOD) (Figure 3A) and catalase (CAT) (Figure 3B)

As for the catalase enzyme (CAT), which removes hydrogen peroxide, it was expected that this enzyme would be more active in low-quality cultivars, since this enzyme is part of the first defense system of the cell when there is oxidative stress with consequent increase of reactive oxygen species (ROS). In this study, the highest expression in the seeds of the cultivars CD 202, Syn 1279 and MS8400 was observed, being the latter classified as having a high physiological quality (Figure 3B). In the seeds of cultivars Syn1263 and CA115, smaller activities of this enzyme were observed. 
On the other hand, Rezende, Salgado, and Chaves (2003) reported that in deteriorated seeds, less activity of this enzyme has been observed, being able to be associated with the lower efficiency of the free radical scavenger systems. Baldoni (2013) also observed variations of this enzyme, both in high and low-quality seeds.

In relation to the isocitrate lyase (ICL) enzyme (Figure 4A), there was a lower expression in seeds of cultivars Syn1263 and Syn1279 classified as of low physiological quality of seeds. Carvalho et al. (2014) found higher ICL activity in soybean cultivars with better physiological quality. In the present research on seeds of cultivars CD201, MS 8400 and CA115, classified as of high physiological quality, a higher expression was also observed, but in seeds of cultivar CD 202, there was a greater expression of this enzyme.

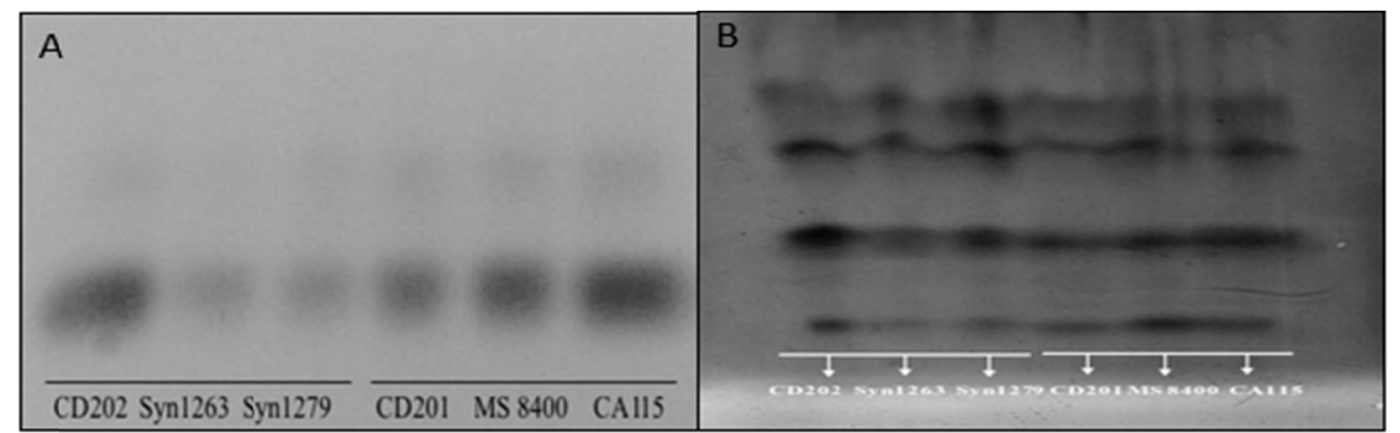

Figure 4. Isoenzymatic patterns in soybean seeds of cultivars CD202, SYN 1363, SYN1279, CD 201, MS8400, CA 115, revealed for the enzyme isocitrate lyase (ICL) (Figure 4A) and esterase (EST) (Figure 4B)

In soybean seeds, ICL is considered a key enzyme in regulating the glyoxylate cycle and is involved in the metabolism of stored lipids in oilseeds and in the development of activities in glyoxysomes. The activity of this enzyme increases during the germination of the seeds, obtaining maximum values when the maximum proportion of degraded lipids occurs for sucrose synthesis (Bewley \& Black, 1994). In this cycle, the insoluble lipids of the seeds are transformed into soluble sugars such as sucrose, which is easily displaced to the root and apical meristems (Cioni et al., 1981).

The zymogram related to enzyme esterase (EST) is shown in Figure 4B. Higher expression was observed in seeds of cultivar CD202, followed by cultivars MS8400 and CA 115. This enzyme acts on embryonic axis growth and lipid breakage in the germination process, especially in oilseeds such as soybean. In some studies with low-quality soybeans, a higher activity of this enzyme has been observed, probably due to changes in cell membrane integrity and seed deterioration (Veiga et al., 2010).

These results may be related to those obtained in the conductivity test, where higher values were observed in seeds of cultivar CD202, followed by cultivars MS8400 and CA115. The electrical conductivity test is based on the principle that, with the deterioration process, leaching of the cellular constituents of water-imbibed seeds occurs due to the loss of the integrity of the cell membranes systems (Hepburn et al., 1984).

Regarding the expression of the glutamate oxaloacetate transaminase (GOT) enzyme (Figure 5A), it was observed higher expression in seeds classified as low quality: CD 202, Syn1263 and Syn1279. GOT plays an important role in the elimination of nitrogen from amino acids, and in the formation of keto groups for the Krebs cycle and gluconeogenesis (Tanksley, 1983). Tunes et al. (2007) associated changes in the number of isoforms of the GOT enzyme with the process of seed deterioration. Similar results were observed by Silva Neta et al. (2014) in corn seeds. 


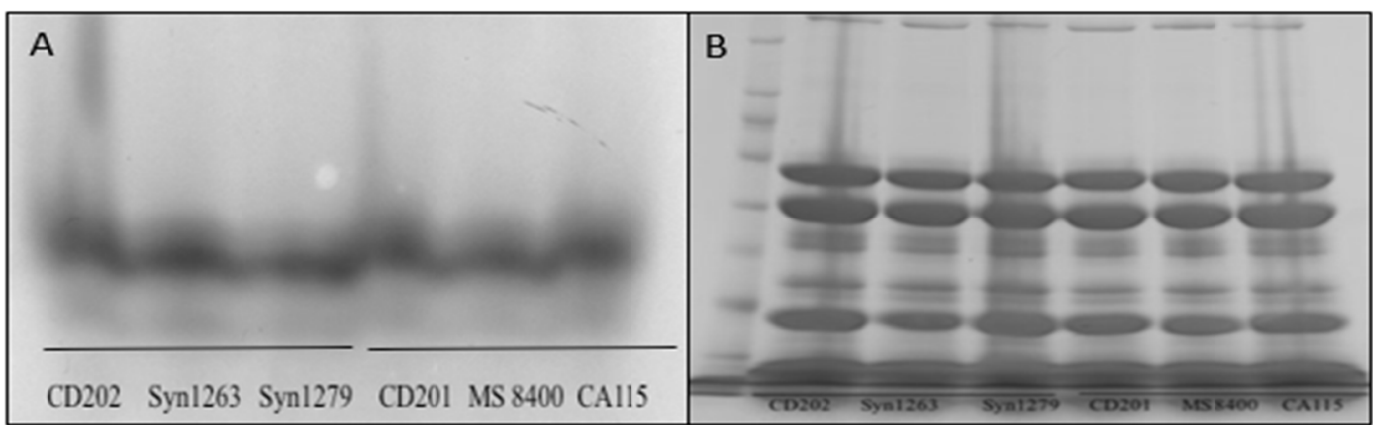

Figure 5. Isoenzymatic patterns in soybean seeds of cultivars CD202, SYN 1363, SYN1279, CD 201, MS8400, CA 115, revealed for the enzyme glutamate oxaloacetate (GOT) (Figure 5A) and heat resistant proteins (Figure 5B)

In the zymogram referring to the expression of heat-resistant proteins (Figure 5b), higher expression was observed in seeds of cultivars classified as low-quality CD202, Syn 1263 and Syn 1279. Heat-resistant proteins are expressed mainly during seed development, and their expression is reduced after germination. These proteins act to maintain the germination rate under stress conditions (Rosa et al., 2005).

Cultivars with seeds classified as high quality showed higher expression of enzymes in the processes related to respiration, examples of alcohol dehydrogenase, malate dehydrogenase, and phosphoglucose isomerase. Higher expression of the enzymes isocitrate lyase and esterase were also observed in seeds of most cultivars classified as high quality. These enzymes are involved in lipid metabolism, important during the seed germination process. In the seeds of these cultivars, the expression of the superoxide dismutase and glutamate oxaloacetate transaminase enzymes was also observed. For the catalase, there was no way to correlate the expression results of this enzyme with the physiological quality of the seeds. For heat-resistant proteins, lower expression was observed in seeds with high quality.

In the gene expression by the qRT-PCR technique, higher expression of the SOD gene was observed in seeds of cultivars SYN1279 and SYN1263, both classified as of low physiological quality (Figure 6A). As in the proteomic analysis, there is also a higher activity of the SOD enzyme in seeds of these cultivars. Lower values were observed in seeds of cultivars CD201, CA 115 and MS8400, classified as of low physiological quality. There was no statistically significant difference between the expression values of this enzyme in seeds of cultivars CA 115 and CD 202.
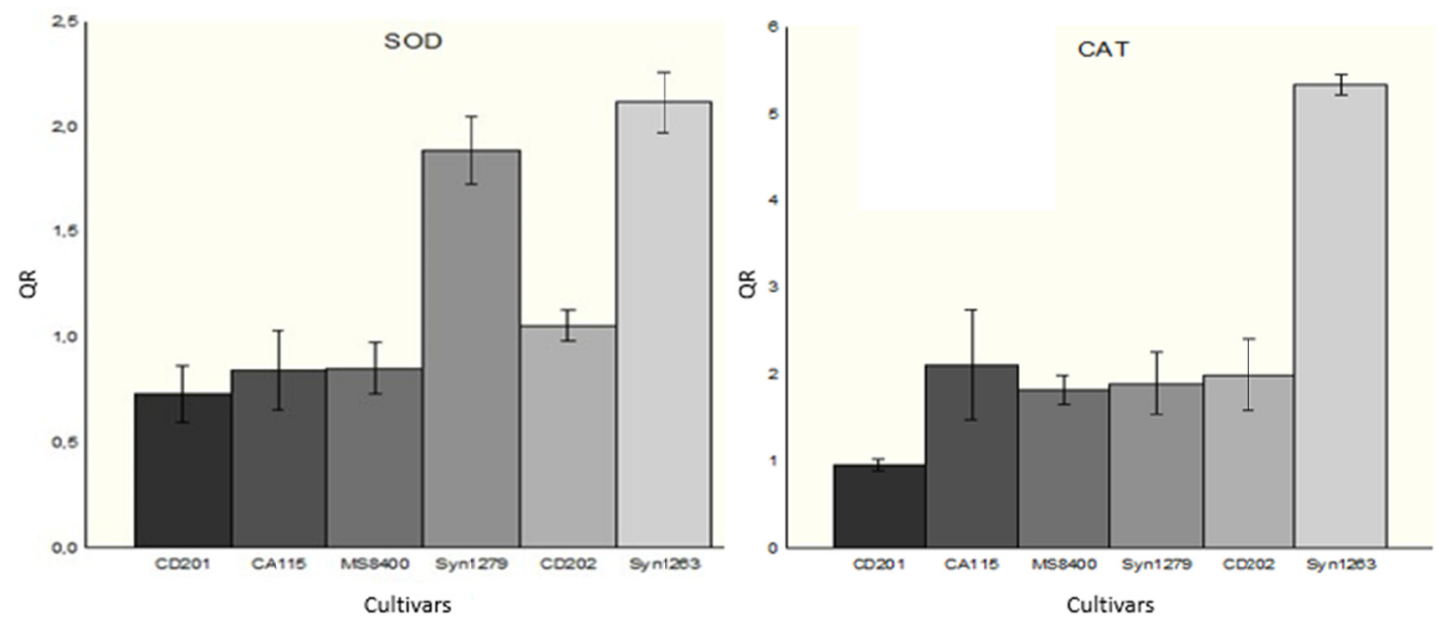

Figure 6. Relative quantitative expression profile of SOD genes (Figure 6A) and CAT (Figure 6B) in high (CD201, CA115, MS8400) and low physiological quality soybean seeds (CD202, Syn 1279, Syn1263)

When analyzing the absolute expression values observed for this enzyme, there was a relation between the results observed in the physiological analyzes of transcript and protein expression. In seeds of low physiological 
quality, there was a greater expression of SOD. This enzyme is associated with the $\mathrm{H}_{2} \mathrm{O}_{2}$ formation in cells. Thus, it is inferred that in soybean seeds of low physiological quality there is the greater formation of free radicals, requiring the expression of this enzyme for its the removal.

The CAT gene (Figure 6B), is also involved in the free radical scavenging system. Higher and lower expression were observed in seeds of cultivars SYN 1263 and CD201, classified as low and high quality, respectively. It is expected that the higher the $\mathrm{H}_{2} \mathrm{O}_{2}$ production by SOD, the greater the expression of catalase for the removal of hydrogen peroxide from the cells. Thus, when analyzing the absolute expression values observed for SOD, it also showed higher values of expression for the same cultivars. Also in relation to CAT, there was no difference in the values observed in the seeds of cultivars CA 115, MS 8400, SYN1279 and CD202. It should be noted that there was a relation when comparing CAT expressions through proteomic and transcriptomic analyzes. Similar results were observed by Baldoni et al. (2013), working with different soybean cultivars in the determination of seed quality and by Silva Neta et al. (2014), working with seed drying in coffee plants.

For the MDH gene (Figure 7A), it was observed higher expression in seeds of Syn 1263 cultivar, followed by seed expression of cultivars CA 115, CD202 and CD 201, with no statistical difference between the values observed in seeds of cultivars CD 201 and CD 202. The lowest expression was observed in seeds of cultivars MS 8400 and Syn 1279. When comparing these results with those observed in the germination and vigor tests, it was not possible to identify a relation between them. In the results of the proteomic analysis, as discussed previously, the highest expression was observed in seeds classified as of high physiological quality. It should be emphasized that in the proteomic analysis the expression of the MDH isoenzyme is evaluated. On the other hand, in the analysis of transcripts, only the expression of the gene was evaluated.
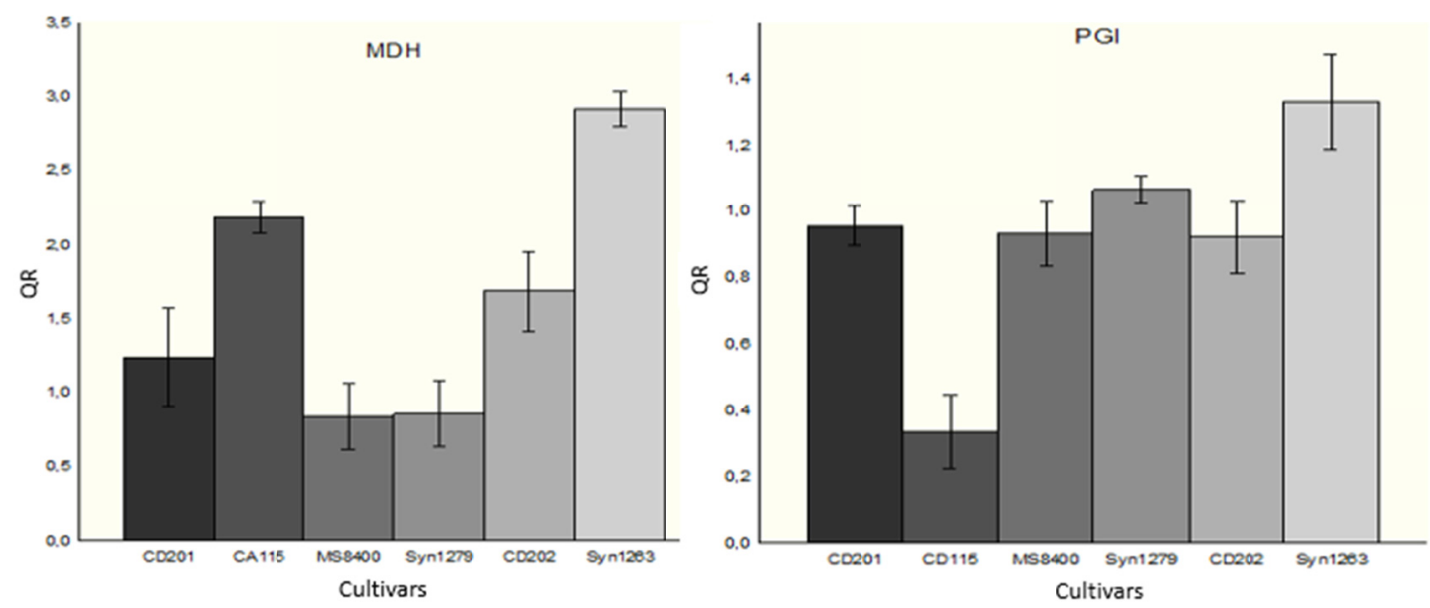

Figure 7. Relative quantitative expression profile of MDH genes (Figure 7A) and PG1 (Figure 7B) in high (CD201, CA115, MS8400) and low physiological quality (CD202, Syn 1279, Syn1263) for soybean seeds

In Figure 7B, the transcript expression profile of PGI is found. The highest expression was observed in seeds of Syn 1263, followed by Syn127 and lower expression in cultivar CA115. PGI is an important enzyme in the respiration process and is expressed in glycolysis. When the expression of this enzyme was evaluated by the electrophoresis technique (Figure 2A), in general, the lowest activity was observed in low-quality seeds. Also for $\mathrm{MDH}$ and $\mathrm{ADH}$, lower activity of these enzymes were observed in seeds of cultivars classified as of low quality (Figures $1 \mathrm{~A}$ and $1 \mathrm{~B})$.

Regarding the expression of the ICL gene (Figure 8A), there were significant differences between cultivars classified as high and low physiological seed quality. The highest expression was verified in seeds of cultivar CA 115, MS8400 and CD20, respectively. These cultivars were classified as high-quality physiological seeds. It is observed a lower expression of ICL in seeds of Syn1263 cultivar, followed by those observed in seeds of cultivars Syn1279 and CD202. These three cultivars were classified as of low physiological quality. When comparing these results with those observed in the proteomic analysis by the electrophoresis technique, it can be noted that there was also a lower expression in low-quality seeds, especially in seeds of Syn1263 and Syn1279 
cultivars. Lower values of expression of this gene were also observed in seeds of cultivars, classified as of low physiological quality in research developed by Baldoni (2013).
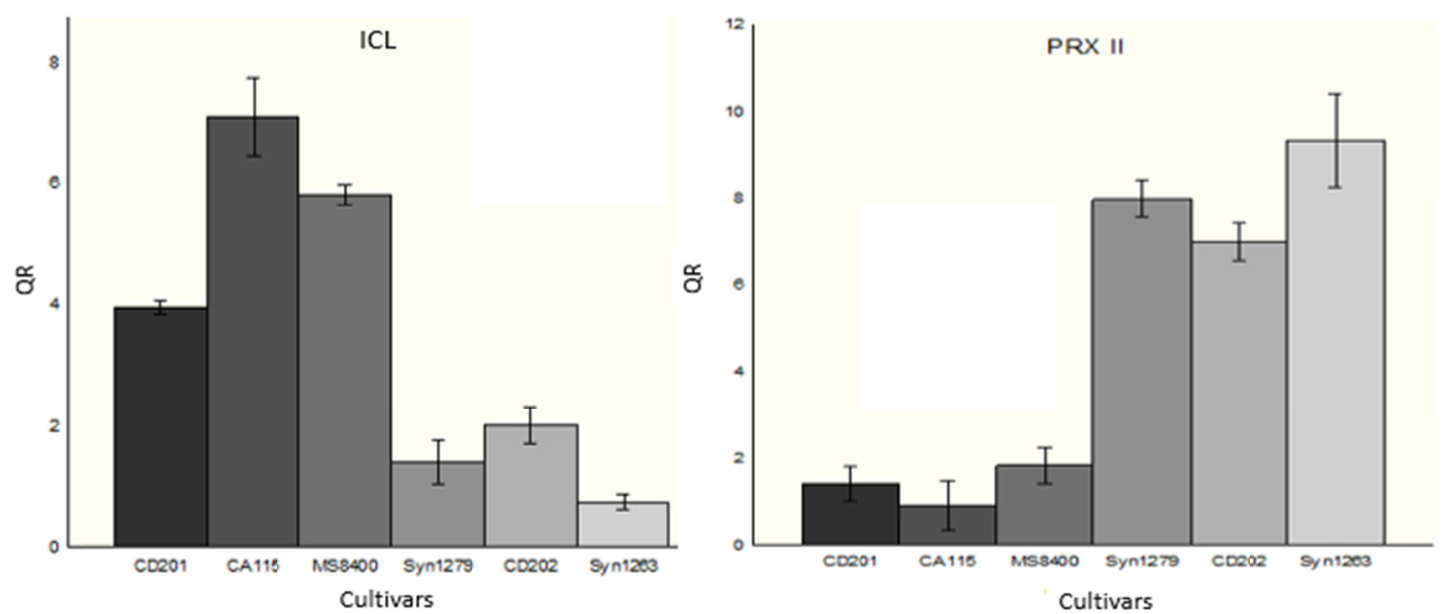

Figure 8. Relative quantitative expression profile of ICL (Figure 8A) and peroxiredoxin (PRx) genes (Figure 8B) in high soybean seeds (CD201, CA115, MS8400) and low physiological quality (CD202, Syn 1279, Syn1263) for soybean seeds

Regarding the expression of transcripts for peroxiredoxin (PRX) (Figure 8B), there was a greater expression in seeds of cultivars Syn 1279 and Syn1263, followed by cultivar CD202, classified as of low physiological quality. The lowest expression values were observed in seeds of cultivars CA 115, CD 201, and MS 8400, classified as having high physiological quality. The PRX enzyme is part of the peroxidase group, which contributes to the control of oxidation cell redox by its ability to reduce peroxide like $\mathrm{H}_{2} \mathrm{O}_{2}$. Thus, in seeds with low physiological quality, the higher expression of this gene may be associated with the removal of $\mathrm{H}_{2} \mathrm{O}_{2}$. An important characteristic of this enzyme is that it is controlled by only a few genes in plants, which characterizes it as a good marker for selection of soybean cultivars.

When evaluating the results of germination and vigor tests, and the transcript and protein evaluations, it shows that the physiological quality trait involves the expression of several genes, which explains the difficulty of correlating, in the present study, the results of transcripts or proteins with the physiological quality of seeds.

\section{Conclusions}

The accelerated aging test for 82 hours classified the cultivars CD201, CA115 and MS8400 as high physiological quality and the cultivars Syn1263, Syn1279 and CD202 as low physiological quality.

Enzymes involved in the respiration process, such as dehydrogenase and phosphoglucose isomerase, are promising markers for assessing the physiological quality of soybean seeds.

Higher expression of the peroxiredoxin enzyme is related to the low physiological quality of soybean seeds.

\section{Acknowledgements}

The authors especially thank to CAPES, FAPEMIG and CNPq, for partially supporting this work.

\section{References}

Baldoni, A. (2013). Expressão de genes relacionados com a qualidade fisiologica de sementes de soja (p. 57, Thesis (Ph.D. in Fitotecnia), Lavras Federal University, Brazil).

Basavarajappa, B. S., Shetty, H. S., \& Prakash, H. S. (1991). Membrane deterioration and other biochemical changes, associated with accelarated ageing of maize seeds. Seed Science and Technology, 19(2), 279-286.

Bewley, J. D., \& Black, M. (1994). Seeds: Physiology of development and germination (2nd ed., p. 445). New York: Plenum. https://doi.org/10.1007/978-1-4899-1002-8

Brasil.(2009). Ministerio da Pecuaria e Abastecimento (p. 395). Regras para análise de sementes. Brasilia, 2009. 
Carvalho, E. R. (2014). Alterações isoenzimáticas em sementes de cultivares de soja em diferentes condições de armazenamento. Pesquisa Agropecuária Brasileira, 38(4), 967-976. https://doi.org/10.1590/s0100-204x20 14001200007

Cioni, M., Pinzauti, G., \& Vanni, P. (1981). Comparative biochemistry of the glyoxylate cycle. Comparative Biochemistry and Physiology, 70(1), 1-26. https://doi.org/10.1016/0305-0491(81)90118-8

Ferreira, V. F. (2015). Adubação com potássio nas características agronômicas e na qualidade de sementes de soja Lavras-MG (p. 105, Thesis (Ph.D. in Fitotecnia), Lavras Federal University, Brazil).

Gasparmalone, P. D. (2007). Expressão diferencial de isoenzimas durante o processo de germinação. Revista Brasileira de Sementes, 29, 61-67. https://doi.org/10.1590/s0101-31222007000100009

ISTA (International Seed Testing Association). (1995). Handbook of vigor test methods. Bassersdorf.

Menezes, M. (2008). Aspectos genéticos asociados a calidad fisiológica de semillas de soya (p. 112, Thesis (Ph.D in Agronomy), Lavras Federal University, Brazil).

Menezes, M. (2009). Aspectos químicos e estruturais da qualidade fisiológica de sementes de soja. Pesquisa Agropecuária Brasileira, 44(12), 1716-1723. https://doi.org/10.1590/s0100-204x2009001200022

Minuzzi, A. (2010). Qualidade de sementes de quatro cultivares de soja, colhidas em dois locais no estado do Mato Grosso do Sul. Revista Brasileira de Sementes, 32, 176-185. https://doi.org/10.1590/s0101-312220 10000100020

Resende, M. L. V., Salgado, S. M. L., \& Chaves, Z. M. (2003). Espécies ativas de oxigênio na resposta de defesa de plantas a patógenos. Fitopatologia Brasileira, 28(2), 123-130. https://doi.org/10.1590/s0100-415820030 00200001

Rosa, S. D. V. F. (2005). Free radical-scavenging enzymes and lea proteins associated to maize seed tolerance to high drying temperature. Revista Brasileira de Sementes, 27(2), 91-101. https://doi.org/10.1590/S0101-31 222005000200014

Rossetto, C. A. V., \& Marcos Filho, J. (1995). Comparação entre os métodos de envelhecimento acelerado e deterioração controlada para avaliação da qualidade fisiológica de sementes de soja. Scientia Agricola, 52(1), 99-105. https://doi.org/10.1590/s0103-90161995000100020

Silva Neta, I. C. (2014). Expressão de genes relacionados à tolerância à baixa temperatura de germinação em sementes de milho (p. 81, Dissertação (Mestrado em Fitotecnia), Universidade Federal de Lavras, Lavras, Brazil).

Tunes, L. M. (2007). Influence of different harvest times on isozyme expression in barley seeds. Revista Ceres, 58(2), 178-184. https://doi.org/10.1590/S0034-737X2011000200008

Veiga, A. D. (2010). Influência do potássio e da calagem na composiçao química, qualidade fisiológica e na atividade enzimática de sementes de soja. Ciência e Agrotecnologia, 34(4), 953-960. https://doi.org/10.159 0/s1413-70542010000400022

Vidigal, D. P. D. (2009). Alterações fisiológicas e enzimáticas durante a maturação de sementes de pimenta (Capsicum annuum L.). Revista Brasileira de Sementes, 31(2), 129-136. https://doi.org/10.1590/s0101-3 1222009000200015

Vieira, R., \& Carvalho, N. M. (1994). Testes de vigor em sementes (pp. 103-132). Jaboticabal: FUNEP.

Zhang, M. (2008). A mechanism of seed deterioration in relation to the volatile compounds evolved by dry seeds themselves. Seed Science Research, 4(1), 49-56. https://doi.org/10.1017/s0960258500001999

\section{Copyrights}

Copyright for this article is retained by the author(s), with first publication rights granted to the journal.

This is an open-access article distributed under the terms and conditions of the Creative Commons Attribution license (http://creativecommons.org/licenses/by/4.0/). 